UDC 316.74

DOI $10.21564 / 2075-7190.43 .187834$

Klimova Galina Pavlovna, Doctor of Philosophical Sciences, Professor,

Professor of the Department of Sociology and Political Science,

Yaroslav Mudryi National Law University, Kharkiv, Ukraine

e-mail:klimova55@gmail.com

ORCID ID: 0000-0002-6533-199X

\title{
THE CONDITIONS OF INNOVATIVE CLIMATE FORMATION IN HIGHER EDUCATION
}

The article is devoted to the theoretical and methodological analysis of the formation of innovative climate in higher education. Internal and external factors influencing this process are analyzed. The article considers the hierarchy of the components of IHE ("education" - "science" - "production of innovations") as its innovative potential.

Keywords: innovation, innovative activity, innovative climate in institutions of higher education, innovative development, innovative society, innovation policy.

Problem setting. The conditions of functioning of higher education significantly change in modern conditions of socio-economic development of Ukraine. The requirements of the state and society to the quality of education are increasing, teaching technologies are being radically updated, organizational and economic conditions of higher education institutions are changing rapidly, the struggle in the educational services market is intensifying. Institutions of higher education should realize their social mission through the implementation of innovative activities, which should be directed to a significant improvement in the quality of higher education; the creation of new intellectual or knowledge-based educational technologies, textbooks and equipment; development of new sources of financing of the IHE; the improvement of work motivation; increase of professional level of the teaching staff; creation of innovative infrastructure and support of its activities, in response to dynamics of external environment and following an internal needs to improve.

For the implementation of innovative activities in higher education institutions, to ensure its innovative development, it is necessary to have an innovative climate in it. All of the above determines the relevance of socio-philosophical analysis of the essence of innovations in the field of higher education, research paradigms of innovation development of higher school, as well as studies of the mechanism of the innovative climate formation that promotes innovative development of higher educational institutions, effective implementation of innovation in higher education. 
Recent research and publications analysis. The problems of formation of innovative climate in higher education are widely discussed in the scientific literature. They are in the focus of such famous scientists as A. Adolph, G. Becker, A. L. Biryukov, E. Bruking, K. Carey, C. Chapman, J. Coleman, P. A. Danaher, K. Daniels, C. Elliott, K. Enomoto, S. Finley, N. F. Ilyin, M. Khosrow-Pour, K. Kusanagi, N. S. Ladizhets, N. I. Lapin, V. S. Lazarev, J. Leonard, J. Lock, B. P. Martirosyan, V. D. Nechaev, C. Nygaard, R. M. Reardon, P. Redmond, H. A. Spires, H. Sugita, F. Takahash, R. Tsuneyoshi, M. V. Volynska, R. Warner, N. L. Yates et al. [1-10]). At the same time, they remain one of the most controversial, as the scientific approaches to their consideration made by different researchers differ significantly from each other. This actualizes the scientific conceptualization of this problem related to the search for conditions for the formation of an innovative climate in the IHE.

Paper objective. In this regard, the article aims to provide a theoretical and methodological analysis of the essence of the innovative climate in higher education, to consider the conditions of its formation.

Paper main body. The Innovation potential is the basic criterion that determines the effectiveness of the process of creating and using innovations in higher education institutions, which characterizes the ability of the university to implement the processes of innovation. The innovation potential of institutions of higher education is a set of different types of resources, including material, intangible, financial, labor, intellectual and other resources which are necessary for the successful implementation of innovation.

The innovative potential of the higher educational institutes is determined by three groups of indicators: 1) indicators of quality of educational services, 2) indicators of the balance of the infrastructure of the institution 3 ) indicators of results of innovative development of higher educational institutions (social, economic, environmental, etc.) [11, p. 7-8].

The state of the innovative potential of the IHE depends largely on the innovative climate, whose characteristics are often crucial for the implementation of innovative goals.

Despite the variety of definitions, the innovative climate is usually interpreted as a set of internal and external conditions, which determine the ability of the University to implement innovative activities successfully.

The internal factors that have a favorable, stimulating effect on this transition include the following: highly qualified teaching staff; rich traditions of the institution in the organization of the educational process, sports and cultural achievements; availability of popular areas of training; developed structure of education after graduation: doctoral, postgraduate, competition, dissertation councils for the defense of candidate and doctoral dissertations; extensive mesh of branches; availability of 
additional professional education potential; the presence of bases of practice for students; providing higher education institution assistance in employment of graduates; availability of monographs, textbooks and scientific and methodological developments, printed on the initiative of the teachers themselves; trends in the growth of IHE and others.

Among the internal factors constraining or limiting the creation of an innovative climate in the IHE, we can mention the following: uncertainty of criteria for selection of educational content; non-compliance of the existing pedagogical technologies of training and control with the modern requirements of the educational process and the quality of training of graduates; insufficient degree of development of fundamental and applied scientific research; gap between theoretical learning and practice; weak susceptibility of the teaching staff to innovations in various industries improvement of the activities of the IHE; lack of an effective system of attracting students to research and the use of research results in the educational process; weak popularization of the achievements of IHE (scientific schools, achievements of graduates); lack of funding for the activities of IHE, insufficient development of material and technical base, information and scientific and methodological support of the educational process, is being modernized; inefficiency of the current system of career guidance; non-compliance of the level of the teaching staff with the growing requirements for the quality of training of students; low salaries of the teaching staff; aging of the teaching staff; the low prestige level of the IHE and other.

Innovative orientation of modernization of higher education is conditioned by various factors of external socio-cultural environment. Among them: political (the presence of a targeted state order for the development and implementation of the state program in the field of youth policy); economic (crisis phenomena in the economy); demographic (fertility decline, family crisis, etc.); cultural and moral (moral degradation, reduction of the level of General culture and education of young people); growing importance of higher education in the world; the presence of competitors in the educational market. These factors together determine the formation of an innovative climate in a particular institution of Higher Education.

We can make some generalizations about the peculiarities of the process of formation of the innovative climate:

1. The specificity of the activities of the IHE (concerns, first of all, technical universities and institutes) is manifested in the fact that they act both as a creative component and as a production component, that is, higher education institutions do not only "produce ideas" at the level of theoretical positions, concepts or scientific justifications. They bring them to the status of "finished products" in the form of experimental and research samples, technologies, programs, technical descriptions or methodological developments (in addition, and this should be emphasized, the IHEs are directly involved to a greater or lesser extent - in the financing of 
basic works related to the process of innovation, and therefore act as a direct investor in innovative projects). Thus, institutions of higher education in this context actually perform three different functions: generation of innovations; production of innovation; providing conditions for spreading of innovation [12, p. 43].

2 . Since the institution of higher education is an integral system, the set of links between all its links also remains unchanged throughout the "production process". This means that during all stages of the innovation process IHE their endogenous environment also remains unchanged, and consequently, the category "innovative climate of the IHE" and "innovation potential of IHE" which are identified by the presence/absence of "information" and "regulatory" links, in fact, become identical.

3 . Each IHE usually has several scientific schools representing different branches of science. It is obvious that the educational and scientific activities of higher education institutions form and develop a stable system of relationships between such schools (primarily on the basis of interdisciplinary connections), makes the teaching staff of different departments to work together to solve certain problems. In turn, such cooperation of scientists from different fields of science leads to: the emergence of the effect of "innovation pressure" within the IHE; the emergence of the effect of "convergence of innovations" [13, p. 57].

4. The presence of a network developed ties with research and design institutes, industrial enterprises and other IHE forms a kind of specific "field", the main "substance" of which is special information (it accumulates technical and economic, technological and other proprietary information), and information for creative nature (it indicates problems and their solutions, which facilitates identification and development of strategies of innovation development. It is obvious that the presence of such a "field" has a decisive influence on the formation of the exogenous environment of the functioning of the IHE. At the same time, it should be noted that the interaction of endogenous and exogenous environments of functioning of higher education institutions leads to the effect of "external innovative pressure" $[13$, p. 35].

It is obvious that some of the generalizations formulated require a more detailed explanation.

The activity of each IHE involves a combination of three main areas: "education", "science" and "producing of innovations". Of course, there is a certain dependence and interdependence between these directions, which forms an integral system of cause-and-effect relations. Thus, the level of "science" is largely determined by the level of "education", which was formed in this institution of higher education.

This is due to the fact that the high "concentration" of scientific and pedagogical workers, as well as the available organizational, institutional and information support create all the necessary conditions for active and effective scientific activity 
of the IHE. On the other hand, a kind of quantitative indicator of the effectiveness of research work, which is carried out in the institution of higher education, is the third direction of its activity - "producing of innovations". That is, the level of "quality of science", which is achieved in a particular IHE, determines the level of direction of "producing of innovations". It should be noted that the level of direction "production of innovations" is characterized as quantitative characteristics (the number of completed developments made experimental and experienced samples obtained certificates on inventions, licenses, patents and the like), and qualitative: every innovation is characterized by its level of innovativeness.

The outlined dependencies between the main activities form an integral hierarchical system of levels: 1st level-the level of "education"; 2nd level-the level of "science"; 3rd level - the level of "development of innovations". At the same time, it is obvious that between these levels there are not only direct links, but also the so - called "positive feedback", that is, the results of higher education institutions in the third direction - the direction of "producing of innovations" - certainly affect its second direction - the level of "science", respectively, strengthening or weakening this direction. A similar relationship exists between the second and first levels: "science" - "education". In other words, the success or failure of IHE in producing of innovations necessarily affects both the level of science and the quality of education in this educational institution, respectively, increasing or lowering them. This hierarchy of components of the IHE is interpreted by many scientists as its innovative potential [14].

We can draw some conclusions, following this approach:

1. A necessary condition for the formation of the innovative climate of higher education institutions is the expressed presence in its activities of three components: "education", "science" and "producing of innovations".

2. A sufficient condition for the creation of an innovative climate of the IHE is the pronounced development, balance and active interaction of these components, the necessary level of which is determined by the presence of a stable system of vertical active links between them.

3. A stable system of vertical active links between "education", "science" and "producing of innovations" in the institution of higher education is provided by an effective system of horizontal links between its structural units (departments).

It can be argued that the level of innovation climate of the IHE is determined by the activity of the system of vertical links, which, in turn, is based on the system of horizontal links.

It is known that the system of horizontal internal links of higher education institutions is a set of links that arise between different departments of the higher education system in the process of their educational and research activities. It is the presence of such a system that provides the opportunity to produce "real" innova- 
tive projects, since their implementation always takes place with the participation of scientists from different departments (that is, representatives of various branches of science). In this case, however, there is one fundamental feature: in the heart of every innovation lies a scientific idea which was developed, as a rule, scientists of one department (that is to say, the relevant department, in terms of innovation orientation), while its implementation is, quite often, is ensured by the participation of scientists from several departments.

Generating a scientific idea profile department creates a kind of internal "innovation pressure" for other departments that are potential participants in the process of implementing this idea in real innovation. As a result, "lagging" departments are forced to pull up to the level that is determined by the level of outlined scientific ideas and the level of its implementation, which certainly leads to the expansion of "bottlenecks" in the process of innovation of higher education institutions. At the same time, it should be noted that this "extension" is often accompanied by the effect of "convergence innovation" [13, p. 57]. The emergence of such an effect directly affects the system of vertical and horizontal links between the components of the IHE, thereby objectively improving its internal innovation climate.

Conclusions of the research. Thus, innovation in higher education institutions does not happen by itself. Certain favorable factors are needed for its implementation, among which the most important place belongs to the formation of an innovative climate in the institution of higher education. The components of the external innovation climate include the state policy in the field of legislation and the tax system, the demand of production and business for innovation products of higher education institutions. An important element of the external innovation climate in the IHE is also the quality of students training, as it determines the success of the implementation of innovative educational programs in higher education institutions. An important component of the internal innovation climate is the presence of initiative highly qualified employees who are able to generate and implement new ideas, as well as competent managers who are ready to adequately perceive the need for change and are able to implement organizational and managerial innovations in institutions of higher education.

\section{REFERENCES}

1. Carey, K. (2015). The end of college: creating the future of learning and the university of everywhere. New York: Riverhead Hardcover.

2. Daniels, K., Elliott, C., Finley, S., Chapman, C. (2019). Learning and teaching in higher education: perspectives from a business school. Northampton: Edward Elgar Publishing.

3. Enomoto, K., Warner, R. \& Nygaard, C. (2018). Innovative teaching and learning practices in higher education. Faringdon, Oxfordshire : Libri Publishing. 
4. Khosrow-Pour, M. (Ed.) (2019). Advanced methodologies and technologies in modern education delivery. Hershey, PA: Information Science Reference.

5. Reardon, R.M., Leonard, J. (Eds.) (2018). Innovation and implementation in rural places: school-university-community collaboration in education. Charlotte, NC: Information Age Publishing, Inc.

6. Redmond, P., Lock, J. \& Danaher, P.A. (Eds.) (2015). Educational innovations and contemporary technologies: enhancing teaching and learning. New York: Palgrave Macmillan, 2015.

7. Spires, H.A. (Ed.) (2018). Digital transformation and innovation in Chinese education. Hershey, PA: Information Science Reference.

8. Trebin, M.P. (2015). Hlobalizatsiia vyshchoi osvity: vyklyky dlia Ukrainy. Materialy II Mizhnarodnoi naukovo-praktychnoi konferentsii "Studentska molod v umovakh hlobalizatsii" (Dnipropetrovsk, 24 kvitnia 2015 r.). - Proceedings of the Second International Scientific and Practical Conference "Student Youth in the Conditions of Globalization" (Dnipropetrovsk, April 24, 2015). Dnipropetrovsk: LIRA, 145-151 [in Ukrainian].

9. Tsuneyoshi, R., Sugita, H., Kusanagi, K., Takahashi, F. (Eds.) (2019). Tokkatsu: the Japanese educational model of holistic education. New Jersey: World Scientific.

10. Yates, N.L. (Ed.) (2015). New developments in science education research. New York: Nova Publishers.

11. Vladimirov, A.I. (2012). Ob innovacionnoy deyatel'nosti vuza: monografiya. Moskva: OOO «Izdatel'skiy Dom NADRA» [in Russian].

12. Vovkanich, S. (2005). Sociogumanisticheskiy kontekst naukoemkoy ekonomiki innovacionnogo obschestva. Ekonomika Ukrainy - Ukrainian economy, 2, 53-58; 3, 42-48 [in Russian].

13. Hrechanyk, B.V. (2007). Innovatsiinospriamovanyi rozvytok pidpryiemstv: orhanizatsiino-ekonomichni aspekty: monohrafia. Ivano-Frankivsk: Zakhidnoukrainskyi ekonomiko-pravnychyi universytet [in Ukrainian].

14. Vladyka, M.V. Innovacionnyy potencial vuzov kak faktor konkurentnosti ekonomicheskogo razvitiya. Retrieved from https://core.ac.uk/download/pdf/151213659.pdf [in Russian].

Клімова Галина Павлівна, доктор філософських наук, професор, професор кафедри соціології та політології, Національний юридичний університет імені Ярослава Мудрого, м. Харків, Україна

\section{УМОВИ ФОРМУВАННЯ ІННОВАЦЙНОГО КЛІМАТУ У ВИЩОЇ ШКОЛІ}

Статта присвячена теоретико-методологічному аналізу формування інноваційного клімату у вищій школі. Аналізуються внутрімні і зовнішні чинники, цио впливають на ией процес. У статті розглядасться ісрархія компонентів $3 В О$ («осві- 
та» - «наука» - «виробництво інновацій») як його інноваційного потенціалу. Стан інноваційного потенціалу ЗВО багато в чому залежить від інноваційного клімату, характеристики якого часто є вирімальними для реалізауї інновауійних цілей. Незважаючи на різноманітність визначень, інноваційний клімат зазвичай трактується як сукупність внутріиніх і зовніиніх умов, від яких залежить здатність $3 В О$ успішно здійснювати інноваційну діяльність.

Можна зробити деякі узагальнення, стосовно особливостей процесу формування інноваційного клімату у $3 B O$ :

1. Специфіка діяльності ЗВО проявлясться в тому, що вона виступас одночасно i як креативна складова, і як виробнича складова, тобто заклади вищой освіти не тільки «продукують ідеї» на рівні теоретичних положень, концепцій або наукових обгрунтувань, вони доводять ӥх до статусу «готової продукиї̈» у формі експериментальних і дослідних зразків, технологій, програм, технічних описів або методичних розробок. Таким чином, заклади вищой освіти в иьому контексті здійснюють фактично три різні функиії: генерування інновачій; продукування інновачій; забезпечення умов для поширення інновацій.

2. Оскільки $3 В О$ с стійкою иілісною системою, то і сукупність зв'язків між усіма п̈ ланками залицається також незмінною впродовж усього «виробничого процесу џ. Це означає, щзо протягом усіх етапів процесу інноваційной діяльності 3 ВО ї ендогенне середовище залишається також незмінним.

3. Кожний 3ВО, як правило, має кілька наукових икіл, ио представляють різні галузі науки. Очевидно, ио освітня та наукова діяльність закладу вицой освіти формуе і розвивае стійку систему взаємозв'язків між такими иколами (в периу чергу, на основі міждисциплінарних з6'язків), змуиуе професорсько-викладацькі колективи різних кафедр спільно працювати над вирішенням тих чи іниих завдань. У свою чергу, така співпраця науковців, які представляють різні галузі науки, призводить до: виникнення всередині ЗВО ефекту «інновачійного тиску»; виникнення ефекту «конвергенції інновацій».

4. Наявність иілоїмережі розвинених зв 'язків з науково-дослідними та проектноконструкторськими інститутами, промисловими підприємствами, а також іниими ЗВО формує своєрідне «спещифічне поле», основною «субстанцією» якого виступас спечіальна інформачія, яка акумулюе техніко-економічну, технологічну та іниу спечіальну інформацію, та інформачія креативного характеру, яка вказуе на проблеми і способи їх розе'язання, сприяс з'ясуванню та розробленню стратегій інноваційного розвитку.

Діяльність кожного ЗВО передбачає поєднання трьох основних напрямів: «освіта», «наука» $i$ «продукування новацій». Безумовно, щзо між цими напрямами існує певна залежність та взаємозумовленість, яка формує цілісну систему причиннонаслідкових зв'язків, які необхідні для формування інноваційного клімату у вищої иколі.

Ключові слова: інновауії, інноваційна діяльність, інноваційний клімат в закладах вищой освіти, інноваційний розвиток, інноваційне суспільство, інноваційна політика. 
Климова Галина Павловна, доктор философских наук, профессор, профессор кафедры социологии и политологии, Национальный юридический университет имени Ярослава Мудрого, г. Харьков, Украина

\section{УСЛОВИЯ ФОРМИРОВАНИЯ ИННОВАЦИОННОГО КЛИМАТА В ВЫСШЕЙ ІШКО.ЛЕ}

Статья посвящена теоретико-методологическому анализу формирования инновационного климата в высией иколе. Анализируются внутренние и внеиние факторы, влияюиие на этот прочесс. В статье рассматривается иерархия компонентов $3 B O$ («образование» - «наука» - «производство инноваций») как его инновационного потенциала.

Ключевые слова: инновачии, инновационная деятельность, инновационный климат в учреждениях высшего образования, инновационное развитие, инновационное общество, инновационная политика.

\section{$\operatorname{soc} 8$}

